This item was submitted to Loughborough's Research Repository by the author.

Items in Figshare are protected by copyright, with all rights reserved, unless otherwise indicated.

\title{
Reaction to the 1622 Virginia Massacre: an early history of transatlantic print
}

PLEASE CITE THE PUBLISHED VERSION

http://www.palgrave.com/page/detail/books-between-europe-and-the-americas-leslie-howsam/?

isb $=9780230285675$

PUBLISHER

(C) Palgrave MacMillan

VERSION

AM (Accepted Manuscript)

PUBLISHER STATEMENT

This work is made available according to the conditions of the Creative Commons Attribution-NonCommercialNoDerivatives 4.0 International (CC BY-NC-ND 4.0) licence. Full details of this licence are available at: https://creativecommons.org/licenses/by-nc-nd/4.0/

\section{LICENCE}

CC BY-NC-ND 4.0

\section{REPOSITORY RECORD}

Armstrong, Catherine M.. 2019. "Reaction to the 1622 Virginia Massacre: An Early History of Transatlantic Print”. figshare. https://hdl.handle.net/2134/18349. 


\section{'Virginia's God Be Thanked': The Use of Print in England in Response to the 1622 Virginia Massacre'.}

During the late sixteenth and early seventeenth centuries, America came to be defined for an English audience through print. Having watched her European rival Spain gain riches and reputation through her colonial activities in Central and South America, England hoped to surpass this example. However, she was unable to establish a permanent colony, despite several attempts in Elizabeth's reign, until April 1607, when three small ships carrying 105 Virginia Company employees arrived in the Chesapeake Bay and established Jamestown. The Virginia Company, one of two joint stock companies created by James I comprising many of the leading businessmen and aristocrats of London, had been awarded a charter the previous year and would be responsible for the political leadership, financial support and provision of manpower for the settlement of Virginia. Their ambition was to create a 'staple' settlement, one that would provide a monopoly market sending commodities to England. Settlers were encouraged to gain control of field, forest and mineral in an area reaching up to one hundred miles from the coast. ${ }^{1}$ The governance of the colony was complicated by the joint control exercised by the Virginia Company in London and the Council, which ran affairs from within the colony itself. On a practical level though, the early settlers came to rely as much on the support of the local Native Americans as their distant paymasters in England. The Indians provided food and shelter for the English settlers, without which the Jamestown colony would have failed just as the Roanoke ventures had done in the 1580s. As it was, a large number of the English settlers died in the first few years, both of famine and disease, problems that were exacerbated by the positioning of Jamestown near stagnant and salty water. ${ }^{2}$

Despite these early tragedies the Virginia colony did survive, although how far it had achieved a measure of stability by the time of the massacre is still a matter for debate. The development of tobacco as a staple crop coincided with the relocation of Jamestown to more sanitary climes and it brought prosperity if not security to the settlers. As the acquisition of wealth came to influence many of the decisions taken for the future of the colony, a locally based elite began to form, leading to the first

\footnotetext{
${ }^{1}$ J. O’Mara, 'Town Founding in Seventeenth Century North America', Journal of Historical Geography, vol. 8 (1982), p. 3

${ }^{2}$ C. Earle, 'Disease and Mortality in Early Virginia', in T. Tate \& D. Ammerman eds., The Chesapeake in the Seventeenth Century, (Chapel Hill, NC., 1979), p. 97
} 
meeting of the representatives of the four boroughs at the Virginia Assembly in Jamestown in 1619. Although most of these early leaders were more interested in growing more tobacco than in establishing a colonial culture, it has been argued that enough gains had been made in the field of education by 1622 that the massacre could be regarded as a real cultural as well as human tragedy for the colony. ${ }^{3}$ However, the existence of the Virginia colony was still a fragile one; in order for it to succeed the Company had to generate interest in England so that investors and migrants would want to participate in the venture. It was also important to encourage young women to move to America to bring a calming influence to the notoriously dissolute colony. All of the migrants in the early years were young men, and so, by 1620, the Company realised that they would have to advertise for women to be their companions, to marry and produce another generation of Virginian settlers and to bring stability and gentleness to the rough life on the American frontier. 'Adventurers' (investors) in England contributed large sums of money towards this project and the first shipment of fifty-seven women arrived late in the summer of 1621 . These women, intended as wives to the planters, made the Atlantic crossing bearing character-references describing their virtues and their housekeeping skills. ${ }^{4}$

The colony's leaders in Virginia had a challenging job, overcoming the environmental problems as well as pulling together the fractious community. In the first decade of settlement, governors such as Thomas Gates and Thomas Dale chose to demonstrate their control by ruling with martial law, although by the time of the massacre, the governor was ruling alongside the council and burgesses in the assembly. The rule of the soldier-governors of Virginia mirrored a pattern that had unfolded in the other colonies and in England itself. Soldiers gained experience of leadership overseas, and then in local garrisons such as Berwick-upon-Tweed and the Isle of Wight. During the Tudor period, soldiers learned domestic policy and had the first hint of American ambition, while in the seventeenth century, a stint in Ireland had taught many of them the qualities needed to supervise new agrarian settlements in potentially hostile environments. ${ }^{5}$

As tobacco growing expanded, more labourers were needed to do the hard work on the plantations, but this had to be balanced with a provision of skilled

\footnotetext{
${ }^{3}$ L.B. Wright, The First Gentlemen of Virginia, (San Marino, CA., 1940), p. 100

${ }^{4}$ For a comprehensive study of origins and experiences of the fifty-seven women who went to Virginia in 1621, see D. Ransome, 'Wives for Virginia 1621', William and Mary Quarterly, 48 (1991), pp. 3-18. ${ }^{5}$ S. Saunders Webb, The Governors-General (Chapel Hill, 1979), pp. 7, 15, 436.
} 
craftsmen and members of the upper classes prepared to lead the colony through its troubled youth. By the time of the massacre, barely a quarter of the settlers being shipped to Virginia survived. ${ }^{6}$ Members of the company in England and America were aware of the importance of providing the reading audience in England with positive reports from Jamestown of present successes and future potential, as well as trying to quash any negative reports being spread by returning sailors or disaffected former settlers. There were varied and diverse networks of communication that linked the colony of Virginia with her supporters and detractors in England, especially if one focuses on the period immediately after the Virginia Massacre of 1622. This is a period that offers particular difficulties to the historian of the book, with the activities of both print maker and consumer shrouded by lack of the sorts of evidence that illuminates the topic in later periods. Printers and booksellers did not keep accurate records as to the production and sale of books during this early period, and so, often the only literature available about a particular printed artefact is its entry into the Stationers’ Company Register.

It was not until 1638 that a printing press was established in the English American colonies, in Boston. But throughout the first half of the seventeenth century the vast majority of American authors chose to have their work printed and distributed in London. Authors aimed their texts at a specifically English readership. Most settlers who ventured into print chose to publish in England not only because the information would be most pertinent to English readers, but also the prestige of the London trade was considerably higher than that of Boston. They could also reaffirm their English identity by sending texts to England, despite the many difficulties such as problems corresponding with proofreaders. ${ }^{7}$ As Pierre Bourdieu says, London was always at the heart of the colonists' cultural world during this period. ${ }^{8}$ A bewildering array of literature was available in print about America during this period, including translations of the exploits of European explorers as well as those written specifically for an English readership. Explorers formed the first wave in the colonial experiment, travelling to America for a short period of a few weeks or months, cataloguing the coastline, the flora and fauna and the climate they found. Writers used a confusing

\footnotetext{
${ }^{6}$ R. Middleton, Colonial America: A History (Oxford, 1992), p. 58

${ }^{7}$ S. Morison, The Intellectual Life of Colonial New England (New York, 1956), p. 118

${ }^{8}$ Quoted in P. Round, By Nature and By Custom Cursed: Transatlantic Civil Discourse and New England Cultural Production 1620-1660 (Hanover, NH, 1999), p. 6. This is supported by David Cressy in his analysis of the communication links between New and Old England: D. Cressy, Coming Over (Cambridge, 1987)
} 
mixture of classical and biblical symbolism, in one sentence describing the landscape as a vacant wilderness awaiting the English plough, and in the next a plentiful Garden of Eden that provided food without labour. ${ }^{9}$ Often these sorts of narratives provided the interested reader with his or her first exposure to the ways of the Native Americans, including physical descriptions of their bodies and clothes as well as information about their day-to-day lives and cultures. Readers of these early narratives were encouraged to judge the Indians as passive and naïve towards the white man, but with a capacity for cruelty towards each other. They were seen as the key to unlocking the great storehouse of commodities provided by the rich landscape.

The authors discussed here were certainly not representative of the majority of migrants to the New World. Very few servants in Virginia put pen to paper, so that the culture from which these texts emerged was that of the leaders: the ministers, military men, adventurers and investors, all of whom had come from the educated classes in England and who would form the political elite in North America. Some wanted to promote investment by wealthy landowners and merchants of England, or to encourage poorer people to advance themselves. Others were worried about Virginia's shortage of labourers, skilled or otherwise, and wanted to encourage poor people to migrate as indentured servants if they were not already trained in a skill useful to the settlers.

The early decades of the seventeenth century saw the birth in England of one of the most popular and enduring forms of print culture: the newspaper. This, too, became a medium through which information about Virginia reached an English readership. These early news sheets and newspapers would have probably been distributed at the same shops and stalls as smaller pamphlets and books, via the printers and bookshops of the St. Paul's churchyard area of London. While it is widely acknowledged that the newspaper proper came to prominence during the Civil War era, there were scattered examples of regular printed news sheets emerging much earlier than that, dating from as early as the time of the Virginia massacre and therefore able to assist in the spread of the unfortunate news. These news sheets were closely related to other genres of print such as the pamphlets that described in lurid detail the latest criminal trials for such notorious crimes as murder, infanticide and witchcraft, or the executions themselves, or such apocalyptic events as monstrous

\footnotetext{
${ }^{9}$ J. Horn, Adapting to a New World, (Chapel Hill, NC, 1994), p. 127
} 
births. However, the true forerunner of the English news sheet was the European example that began appearing on the continent around the turn of the century. One of the earliest weekly summaries of political and military bulletins emerged from Amsterdam in 1607, but only survived for a short time. ${ }^{10}$ These continental news sheets printed official news and offered no personal opinion or 'human interest' stories. English news sheets began around 1622, the year of the massacre, by copying this European format, and, in fact, rarely carried any other news than descriptions of the European armies' activities in the Thirty Years’ War. This makes it all the more surprising that a story, albeit a very brief sentence or two, should be printed about the distant North American colonies, showing the impact of the news of the massacre. Compared to the usual output of authors writing about the New World, this news must have been thought to be very unusual and shocking.

It was not only individuals who put pen to paper to describe events in Virginia during these early years of settlement. The Virginia Company, whose most powerful officials, such as Sir Thomas Smith, were drawn from the members of the elite, close to the king and court, initially used the medium of printed broadsides to convey information. Later, it used small promotional tracts printed in quarto or octavo format, often with less than forty pages, taking the form of a sermon preached by a supporter of the colonial cause, or a positive report from a settler in America. The Virginia Company was always careful in its choice of preacher. In 1609, for example, it used Daniel Price, who had gained the approval of London's merchants by praising them in earlier sermon. ${ }^{11}$ Another of the earliest sermons was by Robert Gray, published in 1609 and intended by the Company to encourage investment in their project and to counter negative reports from Virginia of shortages of food and lack of order. Gray symbolically compared the Virginian migrants to Joshua and the Israelites, arguing that the two main purposes of this American migration would be to assist the multitudes of England by putting them to work abroad, and to 'reduce this people [Native Americans] from brutishness to civilitie'. ${ }^{12}$ The Company also used the experienced preacher Patrick Copland, a passionate and well-travelled supporter of English overseas expansion across the globe, who was at that time involved in raising money for a school in Virginia.

\footnotetext{
${ }^{10}$ J. Frank, The Beginnings of the English Newspaper (Cambridge, MA., 1961), p. 2

${ }^{11}$ L. Wright, Religion and Empire: The Alliance Between Piety and Commerce in English Expansion 1558-1625 (New York, 1943), p. 94

${ }^{12}$ R. Gray, A Good Speed to Virginia (London, 1609), p. 18.
} 
Print was not the only medium chosen by those wishing to convey information from Virginia to England. Many migrants from all social classes, apart from the very lowest, used the medium of manuscript to carry news. Letter writers used it to reassure family and friends that they were safe and prospering, or to persuade the authorities not to abandon them. ${ }^{13}$ The leaders of the colony also communicated privately by letter with the company or the government in England. These texts often included sensitive information they did not want to be revealed to the general public. After the Virginia massacre, as during other sensitive times, many in the company feared that migrants and investors would withdraw support, so it was essential that the release of news was perfectly stage-managed. Other manuscript materials, sometimes not intended for printing, such as an informative letter to an acquaintance, were also the staple material of the great collections of printed travel narratives assembled by Samuel Purchas.

Audiences reacted variously to what they had read, perhaps influenced by the spread of news with negative connotations, such as the threat of forced migrations or the corruption of the colony's leaders. Some readers became authors themselves, incorporating information they had read into their own work. Other authors reflected public interest in the New World by bringing American references into their ballads, plays or poems, sometimes laudatory, though more often satirical. Published works, operating alongside oral networks of information transmission, reached a wide audience from diverse social backgrounds and even negative references helped to raise public awareness of English activity in North America.

When they arrived in Virginia, the English encountered a powerful Native American empire, a loose confederation of Algonquin-speaking tribes under the leadership of Powhatan. ${ }^{14}$ Many settlers and commentators back in England wrongly believed that the natives would easily be subdued and brought under European control, just as a few hundred Spanish had gained control of a powerful and wealthy central American Indian empire nearly a century before. However, the English

\footnotetext{
${ }^{13}$ K. Kupperman, Indians and English (New York, 2000), p. 3

${ }^{14}$ J. Axtell, Natives and Newcomers- Cultural Origins of North America, (Oxford, 2001), p. 233
} 
considered that they were going to behave with more civility than the Spanish, by providing the natives with knowledge that they might become proper human beings while educating them in Christian ways to save their souls as well. ${ }^{15}$

Linguistic and cultural confusion increased the tension between European and Native leading to an incredibly ambivalent relationship between the two. The natives perceived that the Englishmen's power came from their technological advantage: their ability to kill with sophisticated weapons, but they were vulnerable too. ${ }^{16}$ Englishmen were concerned by the military strength of the natives and described living in constant fear of the warlike Indians, although in fact, the natives' assistance helped the settlers get through several harsh winters and Powhatan famously gave his daughter Pocahontas to an Englishman in a marriage alliance. The English could respect Powhatan to a certain extent, he was a leader in the European mould, and the Virginian Indians he governed lived in groups comparable to English shires. ${ }^{17}$ However, the English underestimated the power of Powhatan, believing that he could be easily mastered and manipulated. The English took revenge on entire native populations for the misdemeanours of one or two members of that group and this led the natives to become increasingly hostile. The natives felt that the English were not repaying their hospitality, and their expansionist tendencies were greatly feared. It was this expansion that finally provoked the natives to defend their land, but it also left the English vulnerable. There were no regional centres of settlement in which the English could gather for protection. Tobacco growing had encouraged the settlers to spread out along the James and York Rivers and left them exposed to the Indians' wrath. The deaths of Powhatan and Pocahontas, in 1618 and 1617 respectively, left Powhatan's brother Opecancanough in overall control of the confederacy and he, wanting to move quickly against the English, had the backing of his forces and those of the Chickahominy tribe, thirty of whose number had been massacred by the English in 1614.

The murder by Native Americans on $22^{\text {nd }}$ March 1622 of over three hundred English settlers on several plantations in the Virginia colony, most notably Martin's Hundred and Charles City, not only profoundly affected the policy of the English

\footnotetext{
${ }^{15}$ T. Scanlon, Colonial Writing and the New World: Allegories of Desire (Cambridge, 1999), pp. 113114

${ }^{16}$ J. Axtell, The Invasion Within: The Contest of Cultures in Colonial North America (Oxford, 1985), p. 11

${ }^{17}$ K. Kupperman, Settling with the Indians (New York, 1980), p. 49
} 
towards the original inhabitants of the region, but also eventually sounded the death knell for the Virginia Company itself. Two weeks earlier, a tribal leader known by the English as 'Jack of the Feather' was summarily executed for the supposed murder of an Englishman, Morgan, and this was the trigger for various tribal groups, under the general leadership of Opecancanough, to turn on the English, massacring or taking captive men, women and children, and destroying homes and crops. Native warriors had been allowed to move openly around the English settlements, and some victims even breakfasted with their murderers before the massacre and were killed with their own weapons. The dead and dying were also mutilated, outraging the English survivors and provoking horrific reprisals. The outlying plantations with weaker defences and less manpower were the most severely affected, though Jamestown was only spared a similar fate by an Indian servant, a convert to Christianity, who forewarned the residents of the proposed slaughter. ${ }^{18}$ Even though the colony was saved from total destruction, the massacre did break down the pattern of subsistence living that Virginians had only just achieved for the first time, and several hundred more settlers probably died from famine later in the winter of 1622-3.

Historians have few contemporary accounts with which to reconstruct and verify the chain of events and to follow the network of communication from Jamestown to London. However, those few extant documents speak with a variety of 'voices' because of authorial or editorial intention. The massacre was mentioned in an early news sheet dated July $11^{\text {th }}$ and presumably distributed in the days immediately following, entitled A True Relation of the Proceedings. The short item on the massacre appeared alongside a much larger concentration of European news. ${ }^{19}$ It is clear from the State Papers Domestic that news of the massacre first reached Virginia Company officials in London on July $13^{\text {th }}$ when John Chamberlain wrote to Sir Dudley Carleton informing him, again amongst the reports of other domestic and European matters, that a ship had just arrived and brought news that about 350 of the English settlers in Virginia had been massacred 'through their own supine

\footnotetext{
${ }^{18}$ The most significant interpretation of the impact of the massacre on English policy towards the natives has to be Alden Vaughan, 'Expulsion of the Savages: English Policy and the Virginia Massacre of 1622', William and Mary Quarterly, vol. 35, no. 1 (Jan 1978). I do not propose to revisit his work here, but instead focus on power relations between colony and mother country, between planters and company as illuminated by their connections in print.

${ }^{19}$ J. Frank, The Beginnings of the English Newspaper, (Cambridge, MA., 1961), p. 18
} 
negligence' ${ }^{20}$ This was confirmed the following day by a letter from Sir Thomas Wilson written from his home in the Strand to the Earl of Salisbury, who also mentioned the blessing of the Indian informant's warning to Jamestown without which, Wilson believed, every settler in the entire colony would have been lost. ${ }^{21}$ Ironically, the news of the massacre had taken so long to reach England that, as late as May 1622, Patrick Copland was preaching of the bounty and wonder of Virginia. Copland's sermon was structured around Psalm 107, in which the dangers of crossing the oceans are discussed, clearly relevant to the gathered audience of Virginia Company members. Copland's upbeat address included the assertions that dangers of pirates or enemies at sea had abated, and that the success of the colony after such hesitant beginnings should encourage the audience to praise God. ${ }^{22}$ He was motivating investors to contribute funds towards the establishing of a school for the natives of the region when the massacre had already claimed the life of George Thorpe, the only planter truly committed to the Indian college. Copland raised seventy pounds towards the project and was duly appointed rector of the school, but he was never called upon to use his missionary skills: the college assisted a few English labourers and then corrupt Company officials squandered the rest of the money. ${ }^{23}$

I will just digress for a moment here, to speculate on the possibility that news of the massacre had filtered through to London a few days prior to the official records mentioned above. The Stationers' Company registers record an entry for July $10^{\text {th }}$ in which three ballads were registered, one mysteriously entitled 'Morninge Virginia'. Obviously this title is very ambiguous, it could refer to the colony or an individual woman, and no copies of the ballad have survived to reveal its topic. If it does indeed refer to the tragedy in North America, as is assumed by H.E Rollins, in his Analytical Index to Ballad Entries, then this means that certain individuals had prior knowledge of the massacre, before the planters' letters intended for the Virginia Company had

\footnotetext{
${ }^{20}$ PRO, Domestic Correspondence, Jac I., Vol. CXXXII, no. 38, Cal., p. 424. This contradicts Alden Vaughan's statement that the Seaflower arrived in London in mid-June, for which I could find no evidence. See A. Vaughan, 'Expulsion of the Savages', p. 76.

${ }^{21}$ ibid, no 41, calendar, p. 425.

${ }^{22}$ P. Copland, Virginias God be Thanked (London, 1622), pp. 9, 11.

${ }^{23}$ P. Copland, A Declaration of how the monies...(London, 1622); F. Jennings, The Invasion of America (Chapel Hill, NC., 1975), p. 55. Jennings is typically harsh in his judgement of the Company as a whole, claiming that their missionary attempts were merely a moneymaking sham. However, he does imply that Copland behaved in good faith, and that many of the ministers working for the Company truly believed in the potential of the Virginians to do good works.
} 
reached their destination. The only explanation of this is that word of mouth travelled from the port faster than manuscript.

Such speculations aside, Francis Wyatt, governor of Virginia from 1621-1626, continuously kept his political masters in London informed of the progress of rebuilding the colony after the massacre. Wyatt, inexperienced in leadership, was the eldest son of George Wyatt, a gentleman of Kent, who sent his son a letter of advice on how to govern Virginia in the aftermath of the massacre. ${ }^{24}$ He was also related to the Sandys family, who held key positions in the Virginia Company in both Jamestown and London. Wyatt was upset by the constant criticising of Virginia and tried his best to quash the rumours of hunger and violence that seem to have spread with renewed vigour in the period following the massacre, just as they had done in the first few difficult years of the colony's existence. ${ }^{25}$ His job was a difficult one; not only did he have to defend a weakened Virginia from further Indian attack, but he also had to balance the requirements of an increasingly factionalised Company in London. Wyatt senior recommended his son wage a war of attrition, destroying natives' crops and homes, but George Wyatt did not make the fatal mistake of underestimating the foe. He thought the Indians capable of great courage and advocated a policy of moderation towards innocent natives. ${ }^{26}$ George Wyatt also acknowledged that it was the murder of 'Jack of the Feather' that finally triggered the massacre, something that pamphleteers employed by the Virginia Company did not do for propaganda reasons. Wyatt senior's pragmatic and at times machiavellian letter to his son, existing in two manuscript forms, was not released for printing by the Virginia Company, perhaps as much because of his honest assertions as to the true culpability for the massacre as his controversial tactical advice.

Francis Wyatt's letter, written immediately after the massacre and carried by the Seahorse from Virginia, is to be found in the Records of the Virginia Company and was the source of information mined by Edward Waterhouse who wrote the first account of the massacre to go into print, entitled A Declaration of the State of the Colony and Affaires in Virginia with a Relation of the Barbarous Massacre in the Time of Peace and League, treacherously executed by the Native Infidels upon the

\footnotetext{
24 'A Letter of Advice to the Governor of Virginia 1624', ed. J. F. Fausz \& J. Kukla, William and Mary Quarterly, vol. 34, (Jan, 1977), pp. 104-129

${ }^{25}$ F. Wyatt, 'Letter of Sir Francis Wyatt, Governor of Virginia 1621-1626', William and Mary

Quarterly, $2^{\text {nd }}$ series, vol. 6, no. 2 (1926)

${ }^{26}$ 'A Letter of Advice to the Governor of Virginia', p. 108
} 
English, the 22 of March last. The Stationers' Company records show that Robert Mylbourne registered the Waterhouse tract on $21^{\text {st }}$ August, only five weeks after the first news of the massacre reached England. Waterhouse was a nephew of Sir Edward Waterhouse, former secretary of the Virginia Company, and his pamphlet was intended to defend the behaviour of the company members who felt the spotlight of blame falling upon their shoulders. Waterhouse's history is not clear, though he is named as a 'colonist' in the Dictionary of National Biography. But he did not refer to his own experiences in Virginia to validate the claims made in his tract, which is unusual as many narratives about America during this period used eyewitness testimony to support their arguments. Waterhouse took the opportunity of rehearsing the old arguments about the wealth of flora and fauna, the excellent climate and landscape to be found in Virginia, as well as using a letter written by Wyatt before the massacre to show how unexpected the attack had been. Much of the early part of his work is a direct copy of a tract published by the Virginia Company in the summer of 1620 (and printed again in 1626) to encourage investment in and migration to the colony. Waterhouse spared no venom when describing the behaviour of the natives who were, he said, like ‘bryers’ overrunning a beautiful country, and worse than 'lyons and dragons' because they showed no mercy to those (the English) who fed and clothed them. ${ }^{27}$ By mid August when Waterhouse's tract was published, he was able to write in his epistle dedicatory to the Company that 'the fame of our late unhappy accident in Virginia...is talked of of all men', and that the letters bearing the sad news had already been read in the public court. ${ }^{28}$

John Donne, poet and dean of St. Paul's, and long time supporter of the Virginia enterprise, was chosen by the Company to give a sermon to their members in November 1622. He chose not to refer to the events of the massacre in any great depth, but rather looked to the future. He exhorted the gathered crowd not to give up on Virginia, saying that 'a land never inhabited or utterly derelicted and immemorially abandoned by the former inhabitants becomes theirs that will possess it', but he warned that 'neither does a man become lord of a maine continent because

\footnotetext{
${ }^{27}$ E. Waterhouse, A Declaration of the State of the Colony and Affaires in Virginia (London, 1622), pp. 11,15

${ }^{28}$ Waterhouse, A Declaration of the State of the Colony, sig. A3
} 
he hath two or three cottages in the skirts thereof' ${ }^{29}$ His sermon was printed only days after he gave it, at the request of the Virginia Company.

Christopher Brooke, a poet close to the Stuart court, in his work A Poem on the Late Massacre in Virginia, also published in 1622, acknowledged that the story of the massacre had already been published (probably referring to Waterhouse's work), and chose the genre of tragic poetry as the most fitting means to eulogise those who died. Brooke extolled the virtues of the members of the governing council killed in the massacre, such as Captains Powell and Thorpe, and also praised those who survived, urging them to exterminate the natives: 'the very dregs, garbage and spawne of earth' ${ }^{30}$ There was a simultaneous flurry of transatlantic manuscript communication whose content was at odds with the influence of the printed word. Especially in times of crisis, representations of Virginia in manuscript formats seem to have been more critical than those in printed formats, thus revealing a subversive alternative to the 'story' that Virginia's government hoped to tell. Most notably, a letter from Captain Butler, the former governor of the Summer Isles, heavily criticised the way the colony was governed. He claimed that the colony had been situated on the wrong site, 'upon salt marishes full of infectious boggs', and that the houses built by the settlers were 'the worst I ever sawe the meanest cottages in England beinge in every way equall if not superior with most of the beste'. His most strident criticism was reserved for the governors of Virginia: 'I found in the Government there not onely ignorant and enforced strayings in divers particulars, but willfull and intended ones'. ${ }^{31}$ The following year, a group of planters composed a manuscript answer to Captain Butler defending the governing of the colony, arguing that the disarray in Virginia, and especially its outlying areas, was entirely due to the massacre. John Smith insinuated that Butler had abandoned his post in the Summer Isles, and that his

\footnotetext{
${ }^{29}$ J. Donne, A Sermon upon the VIII verse of the I chapter of the Acts of the Apostles preached...to the Virginia Company (1622), p. 26. It was in this sermon that Donne famously declared 'now I am an adventurer, if not to Virginia then for Virginia, for everyman that prints, adventures', sig. A3.

${ }^{30}$ C. Brooke, A Poem on the Late Massacre in Virginia (London, 1622), sig. C. Prior to the massacre, the English residents who commentated on America were noticeably less hostile towards the natives than the American settlers. Brooke's poem seems to represent a change in direction as his hostile view displaced Copland's desire to educate and reform the Indian. See A. Vaughan, 'Expulsion of the Savages', p. 60

31 'The Virginia Planters' Answer to Captain Butler, 1623', in Narratives of Early Virginia 1606-1625, ed. L.G. Tyler (New York, 1907): electronic version at http://etext.lib.virginia.edu/etcbin/jamestownbrowse?id=J1042
} 
report 'did more hurt then the massacre'. ${ }^{32}$ Butler probably intended his report to be widely distributed, perhaps in printed format, but the Virginia Company managed to protect their reputation by suppressing it. It is clear that the decision by the author, patron or publisher to use scribal or printed media is significant and complex. During the first half of the seventeenth century, print culture was undergoing a radical development. Printed material was becoming available to more people, of the lower social orders as well as the elite, not only because of growing literacy but also because of more comprehensive distribution and a greater public demand for cheap, popular print. ${ }^{33}$ News about Virginia appeared in both small books and pamphlets, affordable to all readers, and also large volumes whose price restricted their sale to all but the most dedicated collector. ${ }^{34}$ However, this did not bring about the immediate decline of what Harold Love has called 'scribal publication'. He claims that texts of great political and intellectual weight were often disseminated in manuscript form. ${ }^{35}$ Much of the manuscript material that this paper is concerned with, such as the Wyatt letters, cannot really be said to have been 'published' at all, as they remained in the hands of an individual or family, and no further copies were made for distribution to other readers. ${ }^{36}$ The exceptions are the multitude of letters and reports, such as Butler's, sent to and produced for the English leadership of the Virginia Company. These reports were distributed in the seventeenth century among members of the Company or the government and occasionally other interested parties. It seems obvious that with the Company choosing to print reports from Virginia on a regular basis, when it did not do so, it reflects a deliberate attempt to manipulate the distribution of the news in England.

By the time John Smith’s epic The Generall Historie of Virginia, New England and the Summer Isles was published for the first time in 1624, the massacre had become old news, but Smith still thought the event significant enough to offer a detailed synopsis of the tragedy, much of it almost identical to the account written by

\footnotetext{
${ }^{32}$ J. Smith, The Generall Historie of Virginia, New England and the Summer Islands (London, 1624), p. 313

${ }^{33}$ For a general discussion of the changes in the distribution and consumption of printed material at the lower ends of the social scale see T. Watt, Cheap Print and Popular Piety 1550-1640 (Cambridge, 1991).

${ }^{34}$ For more on this, see my paper on 'The Bookseller and the Peddler: The Spread of Knowledge of the New World in Early Modern England', presented to the $25^{\text {th }}$ British Book Trade Seminar, Exeter, July 2002. Publication forthcoming.

${ }^{35}$ H. Love, Scribal Publication in Seventeenth Century England (Oxford, 1993), p. vi.

${ }^{36}$ Love states that a manuscript can be called 'published' if it has been disseminated and distributed. I am following his definition. Love, Scribal Publication, p. 36.
} 
Waterhouse two years earlier. Smith also claimed to make use of the letters of 'Master George Sands and many others'. ${ }^{37}$ Smith's interpretations of events differed slightly from those of Waterhouse. Smith made a pointed remark about the misguided authors who thought that the massacre might be good for the plantation, because it gave the settlers an excuse to exterminate the natives, a view that Waterhouse expounded in his pamphlet. Smith argued that 'it had beene much better it had never happened for they have given us an hundred times as just occasions long agoe to subject them', and Smith used his own few difficult years living in the colony, between 1607 and 1609, as an example. ${ }^{38}$ Interestingly, following the massacre, both Smith and Waterhouse held up the Spanish example of bringing the natives to total subjection with only a small force as one to be emulated by the English; the Spanish way of doing things was no longer the 'Black Legend’ of Elizabeth’s reign, reflecting a change in both European politics and in relations between Englishman and Native American.

A tract from Captain John Jeffries registered with the Stationers' Company in July 1624 purporting to contain the latest news from Virginia has sadly now been lost. A new manuscript report did arrive in England in February 1624, but this appears to have been too late for Smith to use in his narrative, which was registered with the Stationers' Company in the July of that year. Based on his observations in Virginia and discussions with local planters, John Harvey’s report for the Privy Council on the state of the colony immediately after the massacre argued that the threat from the natives was growing ever more dangerous, thus perhaps explaining why the report was not offered for publication by the Privy Council, or taken up by Smith or later by editor Samuel Purchas. ${ }^{39}$ This report appeared to seal the fate of the Virginia Company, which had been bankrupted following the king's removal of their right to raise money by holding a lottery in 1621 . The leaders of the Company had managed to annoy James I, who called it 'a seminary for a seditious Parliament', and then proceeded to distribute as many other patents for American settlement as he could to weaken the Virginia Company's position. The charter was dissolved in the early summer of 1624 by the Court of the King's Bench, leading to the creation of England's first royal colony. The taking of Virginia under the crown's wing does not reflect a particularly absolutist desire of James I, who did not really have any plans for

\footnotetext{
${ }^{37}$ J. Smith, The Generall Historie, p. 284

38 ibid, p. 286.

${ }^{39}$ J. Harvey, 'A Brief Declaration of the State of Virginia...' Massachusetts Historical Society Collections, vol. 9, series 4, 1871
} 
the future of the colony. It was a move that was forced on him by the Company's inability to manage its own affairs. Francis Wyatt said that the Company tended to ignore the advice of the Council of Virginia (the governing body within the colony itself) and had heeded the contrary opinions of some of the more aristocratic gentlemen planters, a divisive action which had caused the formation of hostile factions. ${ }^{40}$ On James' death, Charles I took official control of the colony, ruling by a royal governor and royal council, although, significantly for future debates over sovereignty, he did not mention the Virginia Assembly, allowing it to remain in place and to assist with the administration of the colony.

Samuel Purchas used both the layout and content of the published versions of Waterhouse and Smith in his comprehensive edited collection of letters and other documents relating to the history of Virginia, but supplemented these with his own editorial entitled 'Virginia's Verger', a passionate plea to his readers not to abandon the enterprise. As well as emphasising the treacherous nature of the natives who murdered those who had been welcomed to the English tables, Purchas, like Smith, also examined the immediate aftermath of the massacre in which many plantations were closed so that all might live closer together for safety. Like Waterhouse and Smith, Purchas commented on the generous and welcome donation by King James of 'divers armes' from the Tower of London to the colonists. The corresponding order of the Privy Council tells a different story, however. On July $29^{\text {th }}$ 'certain old cast arms in the Tower, altogether unfit for modern use', were offered! ${ }^{41}$ The massacre, and the haphazard way the English authorities reacted to it, caused some writers to turn their adventuring intentions away from Virginia and towards New England. News of the successful landing at Plymouth Rock by the famous separatist pilgrims had begun to filter back to London in the summer of 1622, and the reportedly plentiful supply of fish and timber and the friendly natives intrigued readers. Christopher Levett's voyage of exploration begun in 1623 and the printed report of that voyage were very influential in this change of colonial direction. John Hagthorpe's England's Exchequer, published in 1625, recommended for the greater good of the English nation, investment in navigation and planting overseas by mirroring the Spanish example. He thought Virginia had 'corrupted ayre' and New

\footnotetext{
40 'Governor of Virginia to the Privy Council, 1626’, Virginia Historical Magazine, vol. II (1894-5), p. 51.

${ }^{41}$ S. Purchas, Purchas, His Pilgrims, vol. XIX, (Glasgow, 1957), p. 170; Colonial Correspondence, 1622 July 29, Calendar, p. 32
} 
England and Newfoundland would make more promising settlements as a massacre was unlikely because the 'savages were few and far off'. ${ }^{42}$ Hagthorpe's mistrust of Virginia is revealed in his entry in the Dictionary of National Biography, which says that he was so fearful of becoming destitute through excessive recourse to the law and thus being compelled to migrate to Virginia, that he begged James I for a place for his son at Charterhouse School. By 1622 the great champion of Virginia’s cause, John Smith, was also becoming dissatisfied with the Virginia enterprise, and he too began to focus on New England in his promotional writing.

The massacre caused those who did keep faith with the Virginia colony to drastically change their policy with regard to the Native Americans. No more were English commentators suggesting that in time white man and converted Indian might live side-by-side in North America. From 1622 onwards, the English pursued a relentless campaign of enmity against the neighbouring tribes, whether they had been complicit in the massacre or not. A letter from Robert Bennett to relatives in England showed how commonplace aggression towards the natives had become by June 1623: 'We purpose God willing after we have weeded our tobacco and corne...to goe upon the Waresquokes and Nansemones to cute down the corne and put them to the sorde' ${ }^{43}$ Englishman and native were at war for ten years before an uneasy truce was declared, but fighting broke out again in 1644-46. This time, however, the settlers were too strong and they defeated the natives and captured and killed Opecancanough, the warmonger who had ordered and led the 1622 massacre. The Powhatan confederacy was broken up and their lands taken, a pattern that would be followed across the American continent in the subsequent centuries. ${ }^{44}$

So, how are we to interpret the significance of this flurry of printing activity following the massacre? What were the users of the print medium trying to achieve? How far did the voices of the American settlers become lost as the desperate Virginia Company tried to maintain its authority over them? On the one hand, the transatlantic networks of communication seemed to have worked well in transmitting news of the

\footnotetext{
${ }^{42}$ J. Hagthorpe, Englands Exchequer (London 1625), pp. 29, 33.

${ }^{43}$ J. B. Bodie, 'Edward Bennett of London and Virginia', William and Mary Quarterly, vol. 13 (Apr, 1933), p. 118

${ }^{44}$ R. Middleton, Colonial America: A History (Oxford, 1992), p. 62
} 
massacre, albeit with a delay of three and a half months. The printed reports of Waterhouse, Smith and Purchas were based on the accounts that arrived in London on that fateful July day. However, each author for his own reasons chose to employ the medium of print to distort the story, to put his own slant on the tale, to make it his own. In Waterhouse's case, he wanted to protect his paymasters in the Virginia Company, while both Smith and Purchas believed that England's future lay in her exploitation of overseas colonies. Brooke openly admitted his motivation to write a tragic poem eulogising the dead, and exhorting his readers to revenge upon the perfidious natives. These authors wanted to encourage migration and investment, to protect the colony of Virginia, but theirs was a particularly English version of the story, despite the fact that Smith had lived in Virginia. However, he had not been in Virginia for over ten years and was unable to do much more than relate the massacre to his own encounters with natives during the 'starving time': the first three years of settlement. While Purchas did print a few letters from the planters in full, such as one from Samuel Argall describing the aftermath of the massacre, most were edited and paraphrased by Purchas himself. ${ }^{45}$

In some ways the spread of news about the massacre was beneficial to the Virginia Company as it kept the colony in the forefront of the public imagination at a time when news from New England, the Caribbean and, of course, Europe was taking centre stage. Following the massacre, the whole of London society was once again discussing Virginia. ${ }^{46}$ Its topicality is shown by the play licensed by the Master of the Revels in August 1623 to be played at the Curtain Theatre, entitled 'A Tragedy of the Plantation in Virginia'. 47 The City of London once again acceded to the Company's demand for pauper orphans to be sent to the colony, transporting one hundred children in the autumn of 1622 for the first time in two and a half years. Prior to that the City had not backed out of providing labour because the vagrancy problem had gone away, or because it had a prick of humanitarian conscience, but, rather, simply that there was a lack of interest in Virginia until the massacre brought it back to the public's attention. ${ }^{48}$ Why then, did the Virginia Company and later the Privy Council not encourage or permit the stories direct from the mouths of the Virginia planters to be

\footnotetext{
${ }^{45}$ S. Purchas, Purchas, His Pilgrims, vol. XIX, (Glasgow, 1951) p. 210

${ }^{46}$ W. Billings, Jamestown and the Founding of a Nation (Gettysburg, PN., 1990), p. 50

${ }^{47}$ L.B.Wright, Religion and Empire: The Alliance between Piety and Commerce in English Expansion 1558-1625 (New York, 1943), p. 102

${ }^{48}$ R. Johnson, 'The Transportation of Vagrant Children from London to Virginia 1618-1622', Early Stuart Studies, ed. H.S. Reinmuth, Jr., (Minneapolis, 1970), pp. 145-6
} 
transmitted in print, especially as they were circulating widely in manuscript and their contents had been divulged in the public court? The letter that brought the news of the massacre to England reflected the fears of the men on the ground in Virginia in no uncertain terms. They wrote that the Indians tried to 'cutt us of all and to have swept us away at once through owte the whole lande'. ${ }^{49}$ The description of the horrors of the massacre does not seem to justify the Company's suppression of these letters, but the planters' search for someone to blame for the incident probably caused the Company's reticence. The letter went on 'our first and princypall care should have beene for our safetie', and requested that 'the generall assemblie here may have the full power and awthoritie to remove to such a place'. The planters hinted that it was the greedy company in London, granting patents without thought for the security of the plantation that had caused their difficulties. ${ }^{50}$ The authors of the letter also raised the spectre of famine, as the massacre had interrupted their planting season, and now many felt that it was too dangerous to be outdoors tending one's fields, so they begged their masters in London to send them a 'sufficient portion of corne.' In fact, the only plea that the Company appears to have heeded was for more arms, although as previously mentioned, the quality of the arms they sent to Virginia left a lot to be desired. The attitude of the Company towards its servants is revealed in their reply to that letter on August 1, promising to send more men to fortify the settlement, but patronisingly suggesting that the massacre was a warning from God 'for the punishment of yours and our transgressions'. They told the planters we 'earnestly require the speedie redresse of those two enormous excesses of apparel and drinkeing, the crie whereof cannot but have gon up to heaven'. 51

However, it is also possible to conclude that one can see the work of Waterhouse, Brooke, Smith and Purchas in a very different light. Rather than trying to smother the honest voices of the planters of Virginia with their own sweetened propaganda, it is probable that these authors saw their role as historians of the massacre, and in choosing to gather together information from diverse and disparate sources and distil them into one continuous, chronological narrative, these men were recording, for posterity, the lives and deaths of Virginians whose voices, if remaining

\footnotetext{
49 'Council in Virginia to the Virginia Company in London, April (after 20) 1622', The Records of the Virginia Company, vol. III, ed. Kingsbury, S.M. (Washington, 1908), p. 612

${ }^{50}$ ibid, p. 613

51 'Treasurer and Council for Virginia, Letter to Governor and Council in Virginia: August 1, 1622', Records of the Virginia Company, vol. III, p. 666
} 
only in manuscript, would become fainter and fainter as the years went by. The manuscript letters written in a time of crisis by frightened and lonely men provided the initial burst of news and pleas to those in authority to send assistance, but it was through the use of print that other authors turned the massacre into history. ${ }^{52}$ Of course, within the next few years, print would increasingly become a medium for the transmission of news of a more temporary nature, with the development of the corantos, and, later, newspapers, describing domestic and continental events and the increase in distribution of cheap print products, telling tabloid-like stories of crime and passion. I think that the printed portrayals of the Virginia massacre tell of a more conventional use of print, an attempt to describe a rather classical ideal, recording the tragic lives of a few good men, which may excuse and explain this early development in the transatlantic network of communications between colony and mother-country.

\footnotetext{
${ }^{52}$ For more on the idea of history in early modern England, see Woolf, D. The Idea of History in Early Stuart England (Toronto, 1990) and Woolf, D. Reading History in Early Modern England (Cambridge, 2000). I have also written on early attempts to record the history of America, in 'A New History of the History Book’, paper given to the Book History Conference, Edinburgh April 2002.
} 